\title{
Kajian TIK dan Karakteristik Organisasi: Perbedaan Optimalisasi Internet pada Aktivitas Operasional Lembaga Amil Zakat
}

\author{
Hanifah Permatasari ${ }^{1}$, Indah Nofikasari ${ }^{2}$ \\ Universitas Duta Bangsa Surakarta ${ }^{1,2}$ \\ hanifah_permatasari@udb.ac.id ${ }^{1}$, indah_nofikasari@udb.ac.id ${ }^{2}$
}

\begin{abstract}
Abstrak - Saat ini, internet telah menjadi alat utama dalam perputaran informasi dalam sebuah lembaga. Hal ini dipicu karena berbagai tuntutan yang diterima oleh lembaga, sehingga lembaga tidak hanya memerlukan sebuah alat pengolah informasi yang efisien tetapi juga membutuhkan alat yang mendistribusikan laporan dengan cepat. Salah satu lembaga yang memanfaatkan internet adalah Lembaga Amil Zakat (LAZ). Lembaga ini memiliki banyak cabang, serta menerima tuntutan untuk dapat meningkatkan efektivitas dan efisiensi pelayanan dalam pengelolaan zakat, guna mewujudkan transparansi, akuntabilitas, pelayanan dan jangkauan citra lembaga. Meskipun internet begitu populer dalam distribusi informasi, ternyata ada perbedaan karakteristik organisasi sehingga mempengaruhi perbedaan dalam optimalisasi internet. Tujuan dari penelitian ini adalah menganalisis pemanfaatan internet pada kegiatan operasional LAZ, dan memaparkan temuan-temuan yang diperoleh ketika penelitian. Penelitian ini berhasil mendapatkan informasi dari enam LAZ. Hasilnya, adanya perbedaan kebutuhan organisasi menyebabkan adanya perbedaan pemanfaatan internet. Adapun perbedaan kebutuhan ini dipicu oleh kondisi perkembangan LAZ dan jumlah jangkauan relawan LAZ. Kata Kunci: Internet, Aktivitas Operasional, Lembaga Amil Zakat, Karakteristik Organisasi
\end{abstract}

\begin{abstract}
Currently, the internet has become the main tool in the circulation of information in an institution. This was triggered by various demands received by the institution, so that the institution not only needed an efficient information processing tool but also needed a tool that distributed information quickly. One of the institutions that utilize the internet is the Amil Zakat Institution (LAZ). This institution has many branches, and accepts demands to improve the effectiveness and efficiency of services in zakat management, in order to realize transparency, accountability, service and reach the image of the institution. Even though the internet is very popular in the distribution of information, it turns out that there are differences in organizational characteristics that affect differences in internet optimization. The purpose of this study is to analyze the use of the internet in LAZ operations, and to describe the findings obtained during the research. This study succeeded in obtaining information from six LAZs. As a result, the differences in the needs of the organization lead to differences in the use of the internet. The difference in needs is triggered by the condition of $L A Z$ development and the number of $L A Z$ volunteers outreach

Keywords: Internet, Operational Activities, Amil Zakat Institutions, Organizational Characteristics
\end{abstract}

\section{PENDAHULUAN}

Lembaga Amil Zakat (LAZ) merupakan lembaga yang berfungsi sebagai penghimpun, pengelola, dan pendayagunaan zakat yang telah diberikan legitimasi oleh pemerintah, serta dibentuk oleh masyarakat atau lembaga swasta yang bergerak di bidang dakwah, pendidikan, sosial dan kemaslahatan umat Islam (Pratomo, 2016). Lembaga ini meningkatkan daya guna dan hasil guna zakat dengan pengelolaan secara melembaga dan profesional sesuai dengan syariat Islam yang dilandasi dengan prinsip amanah, kemanfaatan, keadilan, kepastian hukum, terintegrasi, dan akuntabilitas (Indonesia, 2011). Beberapa penelitian sebelumnya menemukan bahwa penghimpunan zakat di Indonesia tidak begitu bagus, mengingat jumlah penghimpunan yang masih rendah apabila dibandingkan dengan potensi zakat (Canggih et al., 2017; Gufroni et al., 2014; Mubarok \& Fanani, 2014). Hal tersebut terjadi karena tingkat kepercayaan masyarakat untuk menyalurkan zakat pada LAZ masih rendah.

Beberapa penelitian terdahulu mencoba menemukan hal-hal yang mempengaruhi kepercayaan masyarakat kepada LAZ. Diantaranya adalah transparansi dan akuntabilitas (Khaerany, 2013; Rahman, 2015; Yuliafitri, Indri; Khoiriyah, 2016), serta pelayanan dan citra lembaga (Nuraini \& Ridla, 2015). Penelitian-penelitian tersebut juga telah memaparkan upaya LAZ dalam mewujudkan transparansi, akuntabilitas, pelayanan dan jangkauan citra lembaga.

Faktanya, LAZ menerima tuntutan untuk dapat meningkatkan efektivitas dan efisiensi pelayanan dalam pengelolaan zakat (Lestari et al., 2015; Lubis et al., 2011). Beberapa upaya untuk mengatur kegiatan operasional, gagasan tata kelola, analisis pengendalian internal dan eksternal, serta penggunaan TIK telah diperhatikan untuk memenuhi tuntutan tersebut (Anwar, 2012; Bayu \& Firdaus, 2015; Gufroni et al., 2014; Hamidi, 2013; Lestari et al., 2015). 
TIK dipahami sebagai sebuah alat yang mampu memudahkan lembaga dalam mengambil keputusan dan membuat rencana strategis, karena keberadaannya dianggap mampu mendukung kegiatan operasional lembaga, termasuk menyatukan dan bertukar data dan informasi dari divisi-divisi yang ada (Hedelin \& Allwood, 2002).

LAZ memiliki beberapa kantor perwakilan dan kantor layanan yang tersebar di berbagai daerah. Seluruh kegiatan operasional LAZ tidak hanya berada di kantor pusat saja, melainkan di kantor perwakilan juga. LAZ perlu berbagi data, dan meletakkan data-data tersebut secara terpusat. Hal ini dikarenakan LAZ harus memberikan laporan kinerja pada BAZNAS dan beberapa pemangku kepentingan yang terlibat. Internet menjadi salah satu alat yang memungkinkan LAZ dapat mengupayakan hal tersebut.

Berdasarkan latar belakang di atas, penelitian ini akan memaparkan pemanfaatan internet pada operasional LAZ. LAZ yang diteliti berjumlah enam, dan memiliki perbedaan pada karakteristik organisasinya.

\section{METODOLOGI PENELITIAN}

Penelitian ini bersifat kualitatif, dan menggunakan metode studi kasus jamak yang melibatkan pada beberapa kasus dan berfokus pada suatu isu (Creswell, 1998). Pelaksanaan penelitian terbagi menjadi empat tahapan seperti pada Gambar 1.

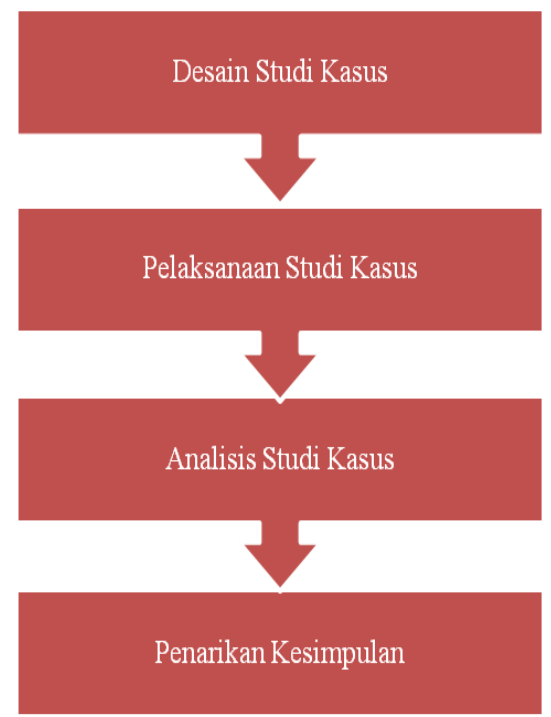

Sumber : (Permatasari \& Nofikasari, 2021) Gambar 1. Tahap Penelitian

\section{A. Desain Studi Kasus}

Belum adanya penelitian terdahulu yang menganalisis pemanfaatan internet pada operasional LAZ di Indonesia, mendorong penelitian ini untuk dilakukan. LAZ yang menjadi obyek penelitian adalah 6 LAZ yang telah mendapatkan izin dan rekomendasi BAZNAS.

\begin{tabular}{|c|c|c|c|}
\hline \multicolumn{4}{|c|}{ Tabel 1. LAZ Studi Kasus } \\
\hline $\begin{array}{c}\text { Inisial } \\
\text { LAZ }\end{array}$ & SKALA & Posısı & $\begin{array}{c}\text { JUMLAH } \\
\text { NARASUMBER }\end{array}$ \\
\hline LAZ A & Provinsi & $\begin{array}{l}\text { Kantor } \\
\text { perwakilan di } \\
\text { kabupaten } \\
\text { (sebelumnya } \\
\text { menjadi } \\
\text { kantor pusat) }\end{array}$ & 1 \\
\hline LAZ B & Provinsi & $\begin{array}{l}\text { Kantor } \\
\text { perwakilan di } \\
\text { kabupaten } \\
\text { (sebelumnya } \\
\text { menjadi } \\
\text { kantor pusat) }\end{array}$ & 2 \\
\hline LAZ C & Provinsi & $\begin{array}{l}\text { Kantor pusat } \\
\text { Kantor }\end{array}$ & 3 \\
\hline LAZ X & Nasional & $\begin{array}{l}\text { cabang di } \\
\text { kabupaten } \\
\text { Kantor }\end{array}$ & 4 \\
\hline LAZ Y & Nasional & $\begin{array}{l}\text { cabang di } \\
\text { kabupaten }\end{array}$ & 3 \\
\hline LAZ Z & Nasional & $\begin{array}{l}\text { Kantor } \\
\text { cabang di } \\
\text { kabupaten }\end{array}$ & 3 \\
\hline
\end{tabular}

(Permatasari \& Nofikasari, 2021)

\section{B. Pelaksanaan Studi Kasus}

Pengumpulan data dalam pelaksanaan studi kasus ini dilakukan dengan pendekatan interpretif, dan dilakukan wawancara dengan teknik snowball sampling (Salganik \& Heckathorn, 2004). Teknik snowball sampling dipilih karena peneliti tidak menunjuk narasumber sebelum melakukan wawancara, akan tetapi LAZ sendiri yang mengarahkan peneliti kepada narasumber-narasumber kunci yang dianggap mampu menjawab pertanyaan. Adapun pertanyaan yang diajukan merujuk pada pemanfaatan internet pada aktivitas kerja.

\section{Analisis Studi Kasus}

Penelitian ini akan menganalisis pemanfaatan internet pada kegiatan operasional LAZ, dan akan memaparkan temuan-temuan yang didapatkan ketika penelitian. Adapun analisis mengenai karakteristik organisasi, merujuk pada referensi-referensi khusus yang membahas organisasi nirlaba. Komponen analisis diantaranya adalah ukuran organisasi, dan proporsi relawan (Hikmet et al., 2008; O'Hanlon \& Chang, 2007).

\section{Penarikan Kesimpulan}

Kesimpulan disajikan dengan menafsirkan konseptual data yang sudah terbentuk untuk menjawab rumusan masalah. Hasil analisis dan temuan yang diperoleh akan dipaparkan dalam bentuk deskriptif. 


\section{HASIL DAN PEMBAHASAN}

\section{A. Pelaksanaan Studi Kasus}

1) LAZ dan Internet

Gagasan untuk menerapkan teknologi internet, telah dibahas pada beberapa penelitian terdahulu untuk memaksimalkan hasil kinerja LAZ. Internet telah digagas untuk e-governance manajemen LAZ (Lestari et al., 2015), optimalisasi kegiatan fundraising (Anggraini, 2018), pengelolaan unit pengumpul zakat (Gufroni et al., 2014), dan pelaporan keuangan (Rini, 2016). Hal ini dikarenakan internet yang memungkinkan antar bagian saling bertukar dan mendapatkan informasi (Spencer, 2002), menjaring publik dan membangun interaktifitas (Waters et al., 2009), serta percepatan akses dan perluasan jangkauan (Shi, 2017).

\section{2) Kegiatan Pengelolaan Zakat}

Definisi menurut UU Nomor 38 Tahun 1999 tentang Pengelolaan Zakat adalah kegiatan perencanaan, pengorganisasian, pelaksanaan, dan pengawasan terhadap pengumpulan, pendistribusian dan pendayagunaan zakat. Adapun fungsi organisasi pengelola zakat adalah sebagai perantara keuangan, dan pemberdayaan (Sartika, 2008).

\section{3) Data Hasil Observasi dan Wawancara}

Berdasarkan hasil penelitian, operasional LAZ meliputi pengumpulan, pendistribusian, dan pendayagunaan. Ini dapat dilihat pada Gambar 2.

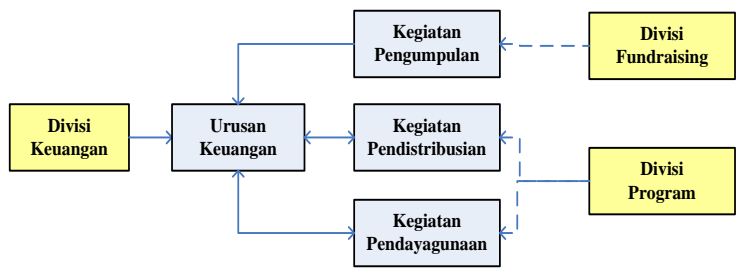

Sumber : (Permatasari \& Nofikasari, 2021)

Gambar 2. Aktivitas Operasional LAZ

LAZ memperhatikan ketersediaan infrastruktur untuk mendukung manajemen pengelolaan zakat karena satu nama LAZ memiliki banyak kantor perwakilan dan kantor cabang yang tersebar di beberapa daerah, serta pentingnya sinergi dan integrasi di dalamnya (Putra et al. 2018). LAZ berupaya untuk menyediakan fasilitas koneksi internet karena internet dapat memberikan keunggulan kompetitif yang strategis (Lee et al., 2001), seperti komunikasi, kolaborasi, kecepatan dan jangkauan, membangun hubungan, efisiensi, integrasi, dan pencapaian donasi (Anheier, 2005; Dumont, 2013; Eveland \& Crutchfield, 2007; Hart, 2002; Pollach et al., 2005) (Anheier, 2005; Dumont, 2013; Eveland \& Crutchfield, 2007; Hart, 2002; Pollach et al., 2005).

\section{a) Pengumpulan}

LAZ memiliki perangkat dan kontak resmi, seperti aplikasi mobile, website, beberapa media sosial, WhatsApp, Phone, dan E-mail. Berdasarkan hasil penelitian, perangkat dan kontak resmi tersebut berfungsi mengoptimalkan penjaringan donasi dan pelayanan; mempublikasikan citra lembaga, visi, misi, program yang dihimpun, pelaksanaan program, dan hasil kinerja ke masyarakat dengan jangkauan yang lebih luas; serta memungkinkan LAZ dapat berinteraksi dengan donatur mengenai konfirmasi atau verifikasi laporan keuangan dan kegiatan.

Selain itu, LAZ yang hanya memiliki rekening pusat untuk kegiatan penghimpunan memaksimalkan koordinasi dalam penerimaan konfirmasi donatur sebelum dicatat pada sistem pencatatan. Hal ini dikarenakan banyaknya karakteristik donatur. Ada donatur yang konfirmasi pada lebih dari satu kantor unit, ada donatur yang transfer tetapi tidak konfirmasi sama sekali, ada donatur yang konfirmasi ke satu kantor unit tetapi tidak menyebutkan namanya, dan ada donatur yang konfirmasi dengan menyebutkan namanya, namun tidak menyebutkan program apa yang akan didonasikan. Adapun koordinasi ini dilakukan melalui whatsApp grup internal. Sementara unit LAZ yang memiliki nomor rekening sendiri, tidak begitu memerlukan komunikasi dengan luar unit. Sebab mereka hanya melaporkan data yang masuk pada LAZ.

Pada kegiatan pengelolaan donatur, beberapa LAZ menggunakan sistem informasi penerimaan terpusat yang berbasis internet. Fungsi internet pada sistem informasi terpusat ini adalah memberikan akses bagi Pusat untuk mendapatkan dukungan data dalam merumuskan rencana strategis dan evaluasi kegiatan pengumpulan pada masing-masing kantor fundraising. Namun demikian, ada LAZ yang menggunakan sistem informasi berbasis internet dan tidak terpusat. Hal ini dikarenakan fokus LAZ adalah ingin mengintegrasikan antara pencatatan data penerimaan donasi dan peruntukan donasi dengan sistem keuangan.

\section{b) Pendistribusian dan Pendayagunaan}

Pada kegiatan ini, LAZ berkordinasi dengan LAZ lain terkait dengan pencarian data penerimaan bantuan, serta pengiriman relawan, pengumpulan, dan distribusi jenis bantuan melalui whatsApp grup Ibnu Sabil Se-Indonesia dan whatsApp grup eksternal. Selain itu, interaksi dengan pihak lain juga dilakukan, seperti interaksi dengan relawan terkait pengumpulan data dan dokumentasi kegiatan di lapangan, interaksi dengan penerima manfaat terkait dengan pelaporan hasil dan capaian kinerja atau distribusi, dan interaksi dengan beberapa pemangku kepentingan terkait secara keseluruhan. Interaksi ini dilakukan dengan melalui perangkat dan kontak resmi. 
Kegiatan distribusi dan pendayagunaan akan berhubungan dengan calon penerima manfaat. Oleh karena itu, LAZ perlu mendokumentasikan rincian data calon penerima manfaat dan penerima manfaat pada seluruh kantor unit LAZ. Dokumentasi ini dilakukan pada Google Drive. Selain itu, ada LAZ yang telah memiliki sistem informasi pelaksanaan program terpusat. Sistem ini memungkinkan pusat untuk dapat memantau kinerja terkait dengan data dan laporan pelaksanaan program kantor unit secara cepat.

\section{c) Urusan Keuangan}

Keuangan adalah salah satu urusan yang sangat diperhatikan oleh LAZ, mengingat kunci dari akuntabilitas dan lulus audit syariah adalah keuangan. Beberapa LAZ telah mencoba menyedikan akses yang mudah untuk kolaborasi seluruh kantor unit dalam membuat laporan keuangan secara cepat dengan Spreadsheet Online. Adapun sistem informasi keuangan terpusat juga telah diterapkan oleh beberapa LAZ, guna membantu pengelolaan data donasi yang masuk di seluruh unit berdasarkan akun akuntasinya, dan memudahkan pusat dalam pemantauan aktivitas pencatatan transaksi masuk dan keluar.

\section{B. Analisa Studi Kasus}

Berdasarkan hasil penelitian, seluruh LAZ telah memiliki fasilitas internet, namun pemanfaatan terhadap fasilitas tersebut tidak seluruhnya sama. Ada LAZ yang memaksimalkan fasilitas tersebut untuk mendukung kinerja seluruh kegiatan operasional, dan ada LAZ yang hanya menggunakan fasilitas tersebut untuk optimalisasi media pada kegiatan fundraising dan mengirim atau menerima berkas elektronik saja.

Tabel 2. Pemanfaatan Internet pada LAZ

\begin{tabular}{llc}
\hline Inisial LAZ & SKALA & PEMANFAATAN INTERNET \\
\hline LAZ A & Provinsi & B \\
LAZ B & Provinsi & A \\
LAZ C & Provinsi & A \\
LAZ X & Nasional & A \\
LAZ Y & Nasional & B \\
LAZ Z & Nasional & B \\
\hline
\end{tabular}

Sumber : (Permatasari \& Nofikasari, 2021) Keterangan :

A : Memanfaatkan internet untuk mendukung kinerja seluruh kegiatan operasional.

B : Memanfaatkan internet untuk optimalisasi media pada kegiatan fundraising dan mengirim atau menerima berkas elektronik.

LAZ yang memaksimalkan fungsi internet adalah LAZ yang memiliki sistem informasi terpusat, atau sebuah tools lainnya yang mampu mengolaborasikan kinerja mereka. Hal ini terlihat pada Gambar 3. LAZ ini memiliki beberapa kantor unit yang tersebar di berbagai daerah, dan manajemen pengawasan yang kuat. Manajemen puncak LAZ ini ingin seluruh data dan informasi yang dimiliki oleh seluruh divisi dapat tersentralisasi, sehingga pembuatan laporan dapat dilakukan dengan cepat tanpa mengabaikan akurasi data.

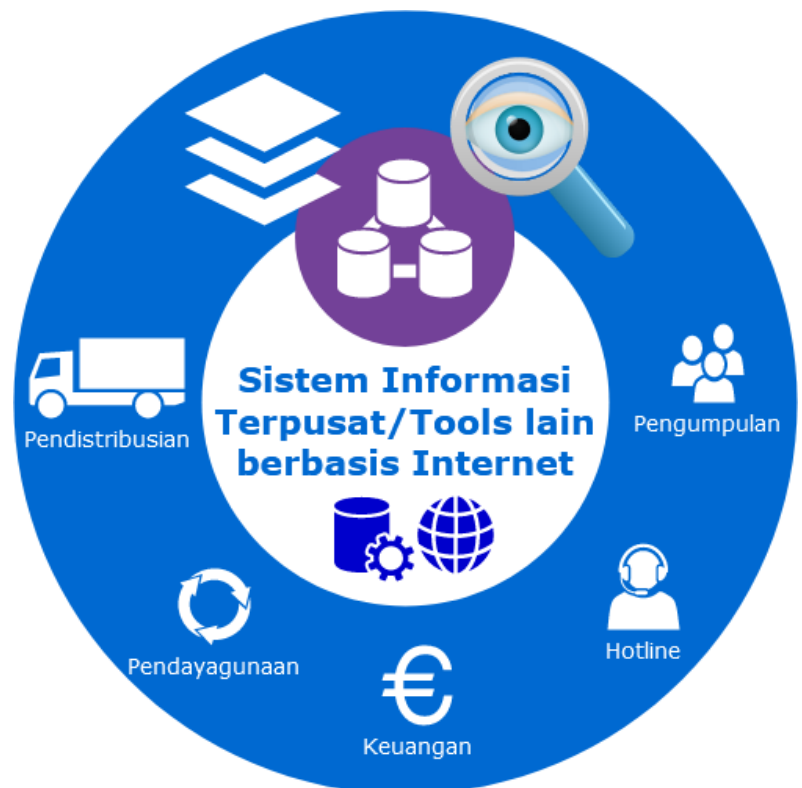

Sumber : (Permatasari \& Nofikasari, 2021)

Gambar 3. LAZ Mengoptimalkan Internet pada Seluruh Aktivitas Operasional

LAZ yang tidak menggunakan internet pada seratus persen aktivitas operasionalnya, bukan berarti organisasi tersebut tidak memperhatikan efisiensi dan kualitas laporan. Urusan keuangan, pencatatan penerimaan, dan pelaporan kegiatan dilakukan dengan aplikasi pendukung seperti Microsoft Word dan Microsoft Excell. Hal ini dipengaruhi oleh kebutuhan dan kondisi LAZ.

LAZ yang sedang berkembang, mereka berusaha menciptakan sistem yang mampu mengefisiensikan kinerja pada seluruh kegiatan operasional sehingga mereka memiliki banyak waktu untuk meningkatkan capaian target penghimpunan. Sedangkan LAZ yang telah lama beroperasi dan memiliki banyak donatur di seluruh Indonesia, lebih fokus pada pencatatan hal-hal yang berhubungan dengan kegiatan operasional mereka. LAZ jenis ini memiliki banyak relawan yang sangat membantu capaian target penghimpunan, sehingga staf operasional hanya fokus pada kegiatan operasional. Artinya, staf tidak terlalu dibebani dengan target penghimpunan seperti $L A Z$ yang sedang berkembang.

Internet akan selalu digunakan untuk mengoptimalisasi sosial media oleh LAZ seperti pada Gambar 4, baik LAZ dengan jumlah relawan yang banyak maupun $L A Z$ yang sedang berkembang. Hal ini dikarenakan 
banyaknya inovasi yang bermunculan terkait cara penghimpunan serta publikasi distribusi dan pendayagunaan. Optimalisasi ini diyakini akan secara signifikan mampu meningkatkan kemampuan organisasi dalam berkomunikasi dengan klien serta regulator, relawan, media, dan masyarakat umum (Waters et al., 2009). Peningkatan kemampuan ini diilhami akan berpengaruh pada reputasi dan kelangsungan hidup LAZ.

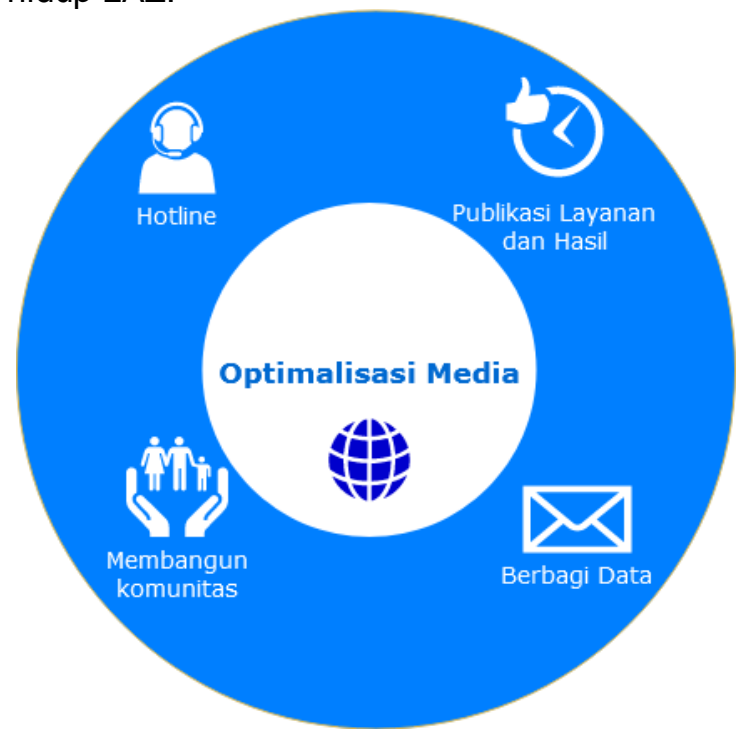

Sumber : (Permatasari \& Nofikasari, 2021)

Gambar 4. LAZ Mengoptimalkan Internet untuk Penggunaan Media

Berbeda dengan organisasi profit, paket internet yang digunakan adalah paket standar. Hal ini dikarenakan terbatasnya anggaran dana untuk operasional, mengingat sumber keuangan organisasi nirlaba sebagian besar berasal dari donasi yang harus dianggarkan kembali untuk kepentingan sosial (Hatten, 2018). Namun demikian, LAZ yang memiliki sistem informasi terpusat telah berusaha mengoptimalkan server dan keamanan, mengingat konsekuensi dari sistem informasi berbasis internet adalah meningkatkan server dan keamanan (Ghatak et al., 2009). Selain itu, ada LAZ yang mengambil langkah lain untuk menghadapi konsekuensi tersebut, seperti menyediakan fitur untuk sinkronisasi data secara terpusat di aplikasi. Jadi internet akan berfungsi hanya ketika fitur sinkronisasi tersebut diaktifkan.

Staf TI LAZ C,

"Sistem informasi yang kami miliki tidak sepenuhnya berbasis online. Sistem kami menyimpan masukan data secara offline, kemudian kami berikan satu tombol untuk mengirimkan data ke pusat. Sebenarnya seluruh kantor kami didukung adanya fasilitas internet. Tetapi, seluruh kantor layanan kami tidak pasti selalu terhubung dengan internet. Misalnya karena daerahnya sedang ada gangguan jaringan yang disebabkan oleh bencana alam, gangguan provider dari vendor, dan lain sebagainya. Kita antisipasi adanya kinerja yang terhambat karena koneksi internet yang terputus, maka kami siasati seperti itu di fitur sistem informasinya."

Hasil dari analisis di atas, dapat dilihat secara ringkas pada tabel berikut :

Tabel 3. Internet sesuai Karakteristik Organisasi

\begin{tabular}{|c|c|c|c|}
\hline SKALA LAZ & RELAWAN & KONDISI & $\begin{array}{l}\text { PEMANFAATAN } \\
\text { INTERNET }\end{array}$ \\
\hline Provinsi & Banyak & $\begin{array}{l}\text { Berkembang } \\
\text { Baik }\end{array}$ & B \\
\hline Provinsi & Sedikit & $\begin{array}{l}\text { Berkembang } \\
\text { Baik }\end{array}$ & $A$ \\
\hline Provinsi & Banyak & $\begin{array}{l}\text { Sedang } \\
\text { Berkembang }\end{array}$ & $A$ \\
\hline Provinsi & Sedikit & $\begin{array}{l}\text { Sedang } \\
\text { Berkembang }\end{array}$ & $A$ \\
\hline Nasional & Banyak & $\begin{array}{l}\text { Berkembang } \\
\text { Baik }\end{array}$ & $B$ \\
\hline Nasional & Sedikit & $\begin{array}{l}\text { Berkembang } \\
\text { Baik }\end{array}$ & $A$ \\
\hline Nasional & Banyak & $\begin{array}{l}\text { Sedang } \\
\text { Berkembang }\end{array}$ & B \\
\hline Nasional & Sedikit & $\begin{array}{l}\text { Sedang } \\
\text { Berkembang }\end{array}$ & $A$ \\
\hline
\end{tabular}

Sumber : (Permatasari \& Nofikasari, 2021)

Keterangan :

A : Internet + Sistem Informasi untuk Efisiensi Kinerja dan Dukungan Akuntabilitas Lembaga.

B : Internet + Media untuk Koordinasi, Komunikasi, Distribusi, dan Publikasi Kinerja

\section{KESIMPULAN}

Berdasarkan pembahasan pada bab-bab sebelumnya, dapat disimpulkan bahwa pada masa kini, LAZ telah menggunakan internet dalam kegiatan operasional. Akan tetapi, adanya perbedaan kebutuhan organisasi menyebabkan adanya perbedaan pemanfaatan internet. Ada LAZ yang memanfaatkannya untuk optimalisasi fundraising saja, dan ada pula LAZ yang memanfaatkannya untuk optimalisasi pada seluruh kegiatan operasional (meliputi fundraising, pendayagunaan dan distribusi, dan urusan keuangan). Adapun LAZ yang mengoptimalkan layanan internet pada seluruh kegiatan operasional adalah LAZ yang memiliki sistem informasi terpusat atau tools lain yang berbasis internet.

Perbedaan kebutuhan tersebut, dipicu oleh perkembangan organisasi dan pertumbuhan relawan. Kedua sebab ini melahirkan konsekuensi yang harus dihadapi oleh masingmasing LAZ, dan berakibat pada pemilihan prioritas tindakan solutif dan kebijakan instansi, sehingga melahirkan kebutuhan yang berbedabeda. Adapun perbedaan karakteristik LAZ sperti skala (Nasional/Provinsi) ternyata tidak menentukan apakah mereka akan 
menggunakan internet pada seratus persen aktivitas operasionalnya. Hal ini dibuktikan oleh LAZ $X$ yang merupakan LAZ Nasional akan tetapi belum mengoptimalkan internet seperti yang dilakukan oleh LAZ lain dalam penelitian ini. Salah satu sebabnya adalah jumlah pertumbuhan relawan yang tinggi, dan kepercayaan masyarakat yang sudah tinggi, sehingga orientasi mereka tidak lagi efisiensi kinerja, akan tetapi publikasi hasil penghimpunan serta penjaringan dukungan mitra dan masyarakat.

Internet selalu menjadi hal menarik bagi LAZ karena kemampuannya dalam menghasilkan strategi yang kompetitif. Oleh karena itu, penelitian selanjutnya diharapkan mampu menganalisis pemanfaatan internet pada target strategi kompetitif LAZ. Penelitian ini telah menemukan bahwa perbedaan kebutuhan menyebabkan perbedaan pemanfaatan internet, sedangkan apabila ada penelitian yang mencoba menghubungan kasus ini dengan target strategi kompetitif mungkin hasilnya akan lebih menarik.

\section{REFERENSI}

Anggraini, D. S. (2018). PERAN MEDIA TERHADAP STRATEGI FUNDRAISING VIA ONLINE DI LAZ NURUL HAYAT CABANG SEMARANG. UNIVERSITAS ISLAM NEGERI WALISONGO SEMARANG.

Anheier, H. K. (2005). Nonprofit Organizations: Theory, Management, Policy. In Social Policy (Vol. 2printing). http://books.google.com/books?id=s_uzgKoVylC\&pgis $=1$

Anwar, A. S. H. (2012). Model Tatakelola Badan Dan Lembaga Amil Zakat Sebagai Upaya Untuk Meningkatkan Pemberdayaan Ekonomi Masyarakat (Studi Pada Badan/Lembaga Amil Zakat Di Kota Malang). Jurnal Humanity, 7(2), 1-13.

Bayu, M. R., \& Firdaus, D. W. (2015). Penerapan Sistem Informasi Manajemen Pada Badan Amil Zakat Nasional (BAZNAS) Dalam Peningkatan Akuntabilitas dan Mutu Pengelolaan Zakat, Infaq dan Sedekah. 109 https://repository.uinjkt.ac.id/dspace/bitstre am/123456789/34154/1/MOCHAMMAD RIZKI BAYU-FDK.pdf

Canggih, C., Fikriyah, K., \& Yasin, A. (2017). Potensi Dan Realisasi Dana Zakat Indonesia. Al-Uqud: Journal of Islamic Economics, 1(1), 14-26. https://doi.org/http://dx.doi.org/10.26740/jie .v1n1.p14-26

Creswell, J. (1998). W.(1998). Qualitative
Inquiry and Research Design: Choosing among Five Traditions, 2.

Dumont, G. E. (2013). Transparency or accountability? The purpose of online technologies for nonprofits. International Review of Public Administration, 18(3), 729.

https://doi.org/10.1080/12294659.2013.108 05261

Eveland, V. B., \& Crutchfield, T. N. (2007). Understanding why people do not give: strategic funding concerns for AIDS-related nonprofits. International Journal of Nonprofit and Voluntary Sector Marketing, 12(1), $\quad$ 1-12. https://doi.org/10.1300/J054v12n01

Ghatak, P., Sachet, G., \& Tham, J. (2009). Promoting Nonprofit Organisations ' IT Enablement in Singapore White Paper: Promoting Nonprofit Organisations ' IT Enablement in Singapore.

Gufroni, A. I., Wisandani, I., \& Sukmawati, H. (2014). Sistem Informasi Unit Pengumpul Zakat Terintegrasi ( Studi Kasus : BAZNAS Kota Tasikmalaya ). Jnteti, 3(4), 236-241. ejnteti.jteti.ugm.ac.id/index.php/JNTETI/arti cle/view/109

Hamidi, N. (2013). Analisis Akuntabilitas Publik Organisasi Pengelola Zakat Berdasarkan Aspek Pengendalian Intern Dan Budaya Organisasi (Survei pada Organisasi Pengelola Zakat di Indonesia). VIII(1), 1334.

Hart, T. R. (2002). ePhilanthropy: Using the Internet to build support. International Journal of Nonprofit and Voluntary Sector Marketing, 7(4), 353-360.

Hatten, M. L. (2018). Strategic Management in Not-For-Profit Organizations Author ( $s$ ): Mary Louise Hatten Published by: Wiley Stable URL : https://www.jstor.org/stable/2486151 REFERENCES Linked references are available on JSTOR for this article: You may need to log in to J. 3(2), 89-104.

Hedelin, L., \& Allwood, C. M. (2002). IT and strategic decision making. Industrial Management and Data Systems, 125-139. https://doi.org/10.1108/0263557021042131 8

Hikmet, N., Bhattacherjee, A., Menachemi, N., Kayhan, V. O., \& Brooks, R. G. (2008). The role of organizational factors in the adoption of healthcare information technology in Florida hospitals. Health Care Management Science, 11(1), 1-9. https://doi.org/10.1007/s10729-007-9036-5 Indonesia, R. (2011). Undang-Undang No. 23 
Tahun 2011 tentang Pengelolaan Zakat. Lembaran Negara RI Tahun.

Khaerany, R. (2013). Akuntabilitas dan Transparansi Lembaga Pengelola Zakat Terhadap Kualitas Lembaga Amil Zakat (Pandangan Muzakki dan Amil Zakat pada Dompet Dhuafa Sulsel). Doctoral Dissertation.

http://repository.unhas.ac.id/bitstream/han dle/123456789/4804/SKRIPSI

RIZKY.pdf?sequence $=2$

Lee, T. E., Chen, J. Q., \& Zhang, R. (2001). Utilizing the Internet as a competitive tool for non-profit organizations. Journal of Computer Information Systems, 41(3), 2631.

Lestari, P., Pratiwi, U., Ulfah, P., Ekonomi, F., Bisnis, D., Jenderal, U., \& Purwokerto, S. (2015). Identifikasi Faktor Organisasional dalam Pengembangan "E-Governance " pada Organisasi Pengelola Zakat. 31(1), 221-228.

Lubis, M., Bilal, M., Lumpur, K., Yaacob, N. I., Omar, Y., Dahlan, A. a, Muharman Lubis, Nurul Ibtisam Yaacob, Yusoff Omar, \& Abdurrahman A. Dahlan. (2011). Enhancement of Zakat Distribution Management System: Case Study in Malaysia. International Management Conference 2011 Proceedings, 1-10. http://irep.iium.edu.my/4261/1/IMAC2011_ EnhancementZakatDistribution.pdf

Mubarok, A., \& Fanani, B. (2014). Penghimpunan Dana Zakat Nasional (Potensi, Realisasi dan Peran Penting Organisasi Pengelola Zakat). Permana, 5(2), 7-16. http://ejournal.upstegal.ac.id/index.php

Nuraini, H., \& Ridla, M. R. (2015). Pengaruh Kualitas Pelayanan, Citra Lembaga dan Religiusitas terhadap Minat Muzakki untuk Menyalurkan Zakat Profesi. Jurnal $M D$, 1(2), 207-228.

O'Hanlon, R., \& Chang, V. (2007). Towards a Model of Internet Technology Adoption for Not-for-profit Organisations. ACIS 2007 Proceedings, Paper 6.

Permatasari, H., \& Nofikasari, I. (2021). Kajian TIK dan Karakteristik Organisasi : Perbedaan Optimalisasi Internet pada Aktivitas Operasional Lembaga Amil Zakat. Bianglala Informatika, 9(2).

Pollach, I., Treiblmaier, H., \& Floh, A. (2005). Online Fundraising for Environmental Nonprofit Organizations. Proceedings of the 38th Annual Hawaii International Conference on System Sciences, 00(C), 178b-178b.

https://doi.org/10.1109/HICSS.2005.470

Pratomo, F. E. K. A. (2016). PADA PEMBERDAYAAN EKONOMI MUSTAHIK JURUSAN EKONOMI SYARI ' $A H$ FAKULTAS EKONOMI DAN BISNIS ISLAM INSTITUT AGAMA ISLAM NEGERI.

Putra, D. A. D., Jasmi, K. A., Basiron, B., Huda, M., Maseleno, A., Shankar, K., \& Aminudin, N. (2018). Tactical steps for egovernment development. International Journal of Pure and Applied Mathematics, 119(15).

Rahman, T. (2015). Akuntansi Zakat, Infak dan Sedekah (PSAK 109): Upaya Peningkatan Transparansi dan Akuntabilitas Organisasi Pengelola Zakat (OPZ). Jurnal Muqtasid, 6(109), 141-164.

Rini. (2016). Penerapan Internet Financial Reporting Untuk Meningkatkan Akuntabilitas Organisasi Pengelola Zakat. Akuntansi Multiparadigma JAMAL, 7(2), 288-306.

https://doi.org/http://dx.doi.org/10.18202/ja mal.2016.08.7022

Salganik, M. J., \& Heckathorn, D. D. (2004). Sampling and Estimation in Hidden Populations Using Respondent-Driven Sampling. American Sociological Methology, 34(2004), 193-239.

Sartika, M. (2008). Pengaruh Pendayagunaan Zakat Produktif terhadap Pemberdayaan Mustahiq pada LAZ Yayasan Solo Peduli Surakarta. Jurnal La Riba (Jurnal Ekonomi Islam), 2(1), 75-89. https://doi.org/10.20885/lariba.vol2.iss1.art 6

Shi, W. (2017). Social Media and Stakeholders ' Relationship in Nonprofit Organizations. 157.

Spencer, T. (2002). The potential of the Internet for non-profit organizations. First Monday, $7(8)$.

Waters, R. D., Burnett, E., Lamm, A., \& Lucas, J. (2009). Engaging stakeholders through social networking: How nonprofit organizations are using Facebook. Public Relations Review, 35(2), 102-106. https://doi.org/10.1016/j.pubrev.2009.01.00 6

Yuliafitri, Indri; Khoiriyah, A. N. (2016). PENGARUH KEPUASAN MUZAKKI, TRANSPARANSI DAN AKUNTABILITAS PADA LEMBAGA AMIL ZAKAT TERHADAP LOYALITAS MUZAKKI. Jurnal Ekonomi Islam, 7(2), 205-218. 